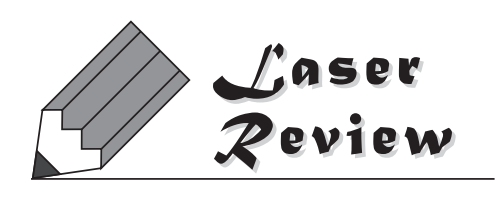

\title{
無線基地局のための光ファイバ給電技術
}

\author{
松浦 基晴 \\ 電気通信大学 ( ₹ 182-8585 東京都調布市調布ケ丘1-5-1)
}

\section{Power-over-Fiber Technologies for Radio-over-Fiber Networks}

\author{
Motoharu MATSUURA \\ University of Electro-Communications, 1-5-1 Chofugaoka, Chofu, Tokyo 182-8585
}

(Received May 22, 2018)

\begin{abstract}
In future radio-over-fiber networks, a huge number of distributed remote antenna units are required to provide various kinds of communication services. Power-over-fiber, which delivers the power required for driving distributed remote antenna units into optical fibers, is an attractive technology to provide cost-effective installation, operation, and maintenance and achieve the power saving in the entire networks. This paper introduces our recent works on power-over-fiber technologies for remote antenna units in radio-over-fiber networks.
\end{abstract}

Key Words: Power-over-fiber, Radio-over-fiber (RoF), Photovoltaic power converters (PPCs), Double-clad fibers (DCFs), Multimode fibers (MMFs)

1. はじめに

スマートフォンの急速な普及やIoT (Internet of Things) の発展に伴い，無線通信のトラヒックは年率50\%にも及 ぶ勢いで増加の一途を辿っている1)。このような状況か ら，第5世代移動通信システム $(5 \mathrm{G})$ では，無線通信の高 速化を目的とした無線信号の高周波数化が進められてい る ${ }^{2)}$ ，その一方，無線信号の周波数が高くなると大気中 での伝搬損失も増大するため，1つのアンテナ無線基地 局でカバー可能な通信エリア(セルサイズ)は必然的に小 さくなってくる。このため, これまで以上に多くの無線 基地局を構築する必要性から, 敷設・管理が容易な無線 基地局の導入が重要な課題となってくる.

無線通信の高速化においては, 光ファイバ通信の導入 も重要となる．光ファイバ無線 (Radio-over-Fiber: RoF) は, 電波 (無線信号)を光信号に変換し, 光ファイバで伝 搬する技術である。 RoFは無線信号を遠方の無線基地局 まで広帯域かつ低損失に伝送することが可能なため，今 後の無線通信においては主流となる伝送技術である.

このような無数に敷設される無線基地局で重要になる のが電源の問題である。通信サービスを稼働させるため には，無線基地局にも必ず電力が必要になる。現状は通 信回線とその関連設備は通信会社が管理・運営し, 電力 に関しては近隣の送電線からの引込みによる商用電源を 利用するのが一般的である。このため, どちらかに障害 が生じると通信サービスは停止する。とりわけ，落雷， 大地震，台風などの自然災害などによる停電はその大き
な要因となっている。実際，2011年の東日本大震災にお いては，無線通信サービスの遮断要因の $85.3 \%$ が停電に よる無線基地局への電力供給停止との報告がある ${ }^{3)}$ 。こ のため, 通信会社としては電源設備も含めた通信と送電 の一括管理を行えるシステムの構築が望まれる。また, 無線基地局あたりの通信トラヒックは，ユーザの移動や 活動時間によって大きく変動するものの, 実際のシステ ムでは通信トラヒックの変動を考慮せず，想定する最大 トラヒック量に対応可能な電力を常に供給している。こ のため, 効率の悪い電力供給を行っているのが現状であ る。これに対し，例えば，夜間にユーザがほとんど不在 のオフィス街などでは, セルサイズの小さい無線基地局 を全て停止し，セルサイズの大きい無線基地局で僅かな 通信トラヒックを賄うことで最大 $60 \%$ の電力削減を出来 るとの報告もあり ${ }^{4)}$, より効率の良い電力供給を行う手 段が求められている。このような電源の問題を解決する 一手段として，著者らは，RoFと電力供給システムを融 合した, 無線基地局のための光ファイバ給電技術の研究 開発を進めている.

光ファイバ給電は, レーザーからの出力を給電光とし て光ファイバ伝送することで，末端の装置を給電光の光 エネルギーで駆動する電力供給システムである，有線電 力伝送という位置づけになるが, 組成材料がガラスであ ることから, 従来の電気ケーブルによる電力線と比較し て，軽量で耐腐食性に優れるなどの特長がある。また, 無誘導媒質のため, 電気を通さない電力線になる。この ため，無線基地局などの高所にアンテナを敷設する設備 
においては，雷害の際，光ファイバで接続された通信設 備への逆電流の被害を阻止する役割を果たすことが可能 である。 また, 光ファイバ給電は複数の無線基地局を管 理する中央局から送電されるため, それぞれの無線基地 局の通信卜ラヒックに応じた電力制御も容易に行うこと が可能である。ささらに, 電源設備の一元化によって電力 設備の管理が格段に容易になる特長がある。一方，標準 的な光ファイバの外径は人間の髪の毛程度の太さ $(125 \mu \mathrm{m})$ で, 光の通り道であるコアはそのさらに1/10程 度の太さであるため, 高出力の給電光を伝送することが 困難である，例えば，遠隔のカメラを駆動する光給電力 メラシステムでは, 監視用カメラシステムとして, 給電 用および映像信号用の2本の光ファイバで伝送を行う構成 で最大 $400 \mathrm{~mW}$ 出力光パワーを送電している5 山間部などの電力を自由に確保出来ない場所において, 受信点で受信した放送波を, 光給電で駆動する光送信器 を用いて送信所に伝送する無給電光伝送装置がある。こ れも給電用および信号用の光ファイバを別にして, 最 大 $300 \mathrm{~mW}$ 程度の出力光パワーを送電している6).いずれ においても遠隔地に供給可能な電気電力は $100 \mathrm{~mW}$ 以下で ある。これに対し, 著者らが提案している光ファイバ給 電では無線基地局の駆動を目的としているため, 最低で も数Wの電気電力を供給する必要がある.

本論文では，無線基地局の駆動を目的とした光ファイ バ給電技術について, 著者らの取り組んでいる研究成果 を解説する。

\section{2. 給電用光ファイバ}

無線基地局向けの光ファイバ給電においては, 既存の 光アクセス系の光ファイバ敷設状況を考慮した導入が重

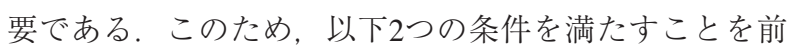
提として, 研究開発を進めている。第一に, 1本で信号 と電力の同時伝送が可能な光ファイバを使用する. 光ア クセス系の光ファイバ敷設においては, 無線基地局も含 めた終端装置の数が膨大で, 将来的な増設の必要性から も余分な光ファイバを敷設する余裕はないため, 給電用 の光ファイバを別途敷設するのは現実的ではない。この ため, 1本の光ファイバで信号と電力の同時伝送を行え る光ファイバが必要となる. 第二に, 使用する光ファイ バのクラッド外径は現在敷設されている光ファイバと同 じ $125 \mu \mathrm{m}$ をす。現在の光アクセス系では全て，ク ラッド外径 $125 \mu \mathrm{m}$ で規格化された構成になっているた め, 新たに導入される給電用の光ファイバにおいても, これに準拠したものを使用することが望ましい.

Fig. 1 に上記の条件を満たす4つの光ファイバの断面 図を示す。単一モード光ファイバ(Single-Mode Fiber: SMF) は光ファイバ通信で最も利用されている光ファイ

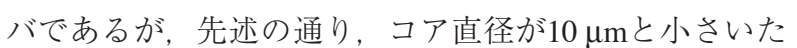
め, 高パワーの伝送には不適で供給可能な電力

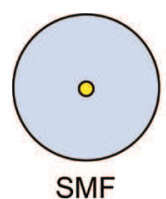

(a)

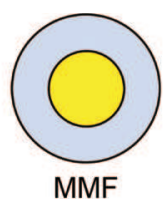

(b)

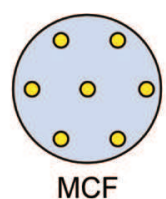

(c)

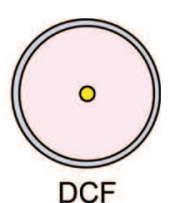

(d)
Fig. 1 Cross section of various optical fibers for power-over-fiber. (a) Single-Mode Fiber (SMF), (b) Multimode Fiber (MMF), (c) Multi-Core Fiber (MCF), and (d) Double-Clad Fiber (DCF).

は100 mW以下である ${ }^{+1, \uparrow 2}$. RoF伝送用の光ファイバ給電 への検討も行われていたが, 小型の無線LANスポット などの数十 $\mathrm{mW}$ の電力で駆動可能な基地局を目的として いた5). 多モードファイバ(Multimode Fiber: MMF)も沉 用性の高い光ファイバだが，コア径が大きいことで，光 信号が伝搬する際に発生するモード分散によって伝送帯 域が制限されるという問題がある吕．また，SMFや MMFのような単一コアの光ファイバで信号と電力の同 時伝送を行う際には，膨大なパワーを有する給電光の強 度摇らぎや雑音等が信号光にクロストークを与える場合 がある. マルチコア光ファイバ (Multi-Core Fiber: MCF) は, クラッド内に複数のコアを有する光ファイバであ る。製造工程は複雑であるが，1本の光ファイバでコア 数分の伝送路を確保することが可能である，光ファイバ 給電に拈いては, 信号光を 1 コア, 給電光を他の複数コ アを利用することが可能で，これまでにMCFを用いて 電気増幅器を内蔵した光電変換モジュールを駆動する実 証実験も報告されている7)。 これらに対して, 著者ら は，ダブルクラッド光ファイバ(Double-Clad Fiber: DCF) を用いた光ファイバ給電を提案している. DCFはFig. 1 (d)に示すように, 単一モード (Single-Mode: SM)コアの 外側に内部クラッドを有する2重コア構造の光ファイバ である，信号光をSMコア，給電光を内部クラッドで伝 送することで，信号光はSMFと同様に広帯域伝送を可能 とし, 給電光については, 大口径の内部クラッドを用い る.これにより, 他の光ファイバと比べて, パワー伝送 用のコア面積を格段に大きく確保することが可能であ る。本論文では，著者らが提案しているDCFを用いた光 ファイバ給電技術と, MMFでのモード分散拉よび給電 光クロストークの抑制を可能とする光ファイバ給電技術 を解説する。

\section{DCFを用いた光ファイバ給電技術}

DCFはこれまで主に光ファイバ増幅器や光ファイバ レーザーの利得媒質として利用されてきた。SMコアに 希土類元素を添加し, 高パワーの励起光を内部クラッド に入射することで高利得が得られる構成となっている. 一方, 光ファイバ給電用のDCFでは, 伝送媒質として利 用するために，SMコアに希土類元素を添加しないDCF

\footnotetext{
†1 古河電工 : 光給電カメラ https://www.furukawa.co.jp/fitel/system/products/unit.htm

${ }^{\dagger 2} \mathrm{NHK}$ アイテック：無給電光伝送装置 http://nhkitec.com/images/catalog/001.pdf
} 
を用いる。これまでに著者らが報告してきたいくつかの 成果があるが ${ }^{8-13)}$ ，本論文では最近報告したマルチチャ ネル伝送の実証実験 ${ }^{13}$ について以下に解説する。

Fig. 2 に実験構成を示す。基本構成は中央局 (Central Office: $\mathrm{CO}$ ) と無線基地局 (Remote Antenna Unit: RAU) 間 を想定したRoFの下り伝送になっている。信号光には単 一チャネルの光アナログ信号 (Ch. 3) と4チャネルの光デ ジタル信号 (Ch. 1，2，4，5)を用いて抢り，それぞれ のチャネル間隔は一般的な波長多重伝送を想定し た $100 \mathrm{GHz}$ で配置されている, 光アナログ信号は, 半導 体レーザー (Laser-Diode: $\mathrm{LD}$ ) からの出力を $\mathrm{LiNbO}_{3}$ 変調器 $\left(\mathrm{LiNbO}_{3}\right.$ Modulator: LNM) によるアナログ変調で生成し ている。データ信号には無線LAN規格に準拠したキャ リア周波数 $5.2 \mathrm{GHz}$ の信号を使用している. 光デジタル 信号は波長の異なる4台のLD出力を1台のLNMを用い て, 4チャネルの伝送速度 $10 \mathrm{Gbit} / \mathrm{s}$ ) NRZ-OOK (Nonreturn-to-zero, On-off keying) 信号を生成している。これら の信号は増幅後, 光カプラ (Optical Coupler: OC) を用い て合波され，クラッドモードストリッパー(Cladding Mode Stripper: CMS)に入力される。このCMSは給電光の反射 成分がDCF入力側のSMFに出射させないために用いてい る. 給電光には, 波長 $808 \mathrm{~nm}$ の台の高出カレーザー (High-Power Laser-Diode: HPLD) を用いて, 合計60 Wの 光パワーをDCFに入力している. 信号光と給電光はテー パファイババンドル型の合波器(Tapered Fiber Bundle Combiner: TFBC) で合波される。この際, 信号光はその ままSMコアを伝搬し, 給電光はテーパファイバによっ て, DCFの内部クラッドに入射される構成となってい る. 実験に使用したDCFは伝送路長 $300 \mathrm{~m} て ゙, S M コ ア$ 直 径が9 $\mu \mathrm{m}$ ，内部クラッド直径が $105 \mu \mathrm{m}$ のものを使用し た. 伝送後, 信号光と給電光はテーパファイババンドル 型の分波器(Tapered Fiber Bundle Divider: TFBD) で分波 される. 合波器同様, 信号光はそのままSMコアを伝搬 するが, 給電光は6本のテーパファイバによって, 内部 クラッドから給電光成分を取り出している。この構成で およそ70\%の給電光を 6 本のMMFで抽出している. 残り の30\%はTFBDを透過し, 後段のCMSで吸収されてい る. それぞれのMMFは6台の光電変換素子(Photovoltaic Power Converter: PPC) に接続され, 電気電力に変換して いる. CMSを通過した信号光は, それぞれの受信器に
分波され，フォトダイオード(Photo-Diode: PD)で電気信 号に変換された後，アナログ信号はシグナルアナライザ (Signal Analyzer: SA)を用いたエラーベクトル振幅 (Error Vector Magnitude: EVM)の評価，デジタル信号は符号誤 り率検出器 (Bit Error Rate Tester: BERT) を用いた符号誤 り率 (Bit Error Rate: BER)の評価によって, 給電光パ ワーに対する伝送品質の測定を行っている.

Fig. 3 に給電光のパワー伝送特性を示す。（a）はHPLD の出力光から PPC前段までの光パワー伝送効率, すなわ ち, 伝送系全体の損失を示す。 (b) はHPLDの出力光か らPPCで変換された電気電力までの伝送効率を示す。図 より，伝送系に扔いては，平均で拈よそ $48.5 \%$ の゚゚ワー

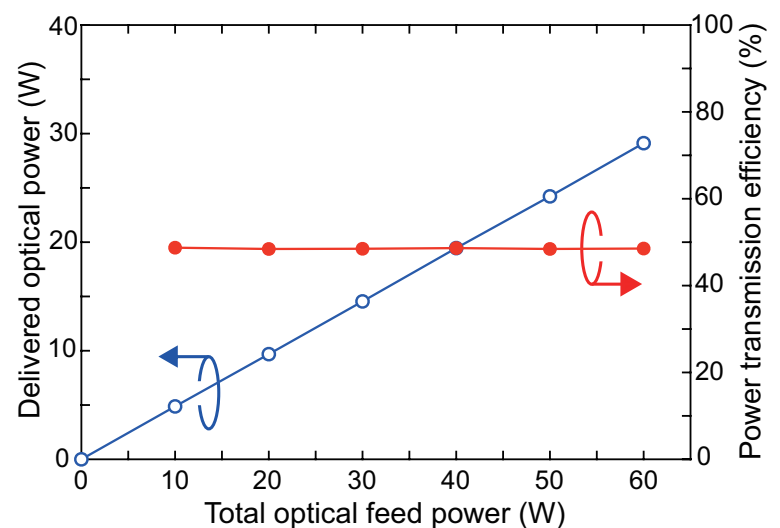

(a)

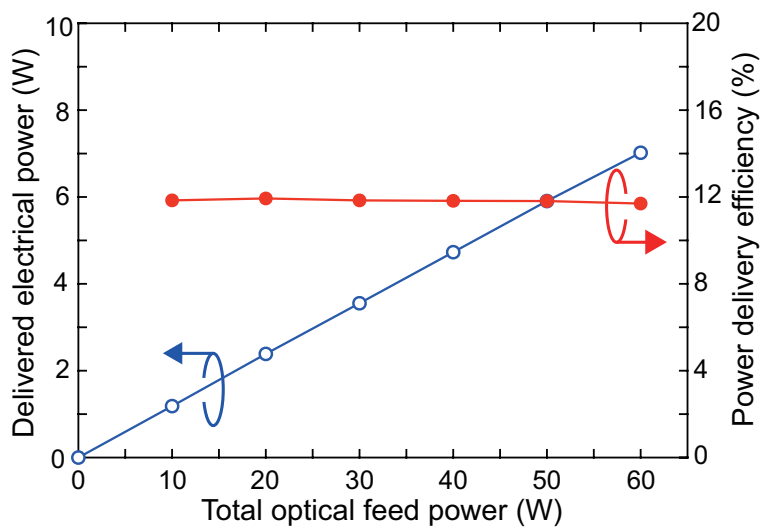

(b)

Fig. 3 (a) Power transmission efficiency and (b) Power delivery efficiency as a function of total optical feed power.

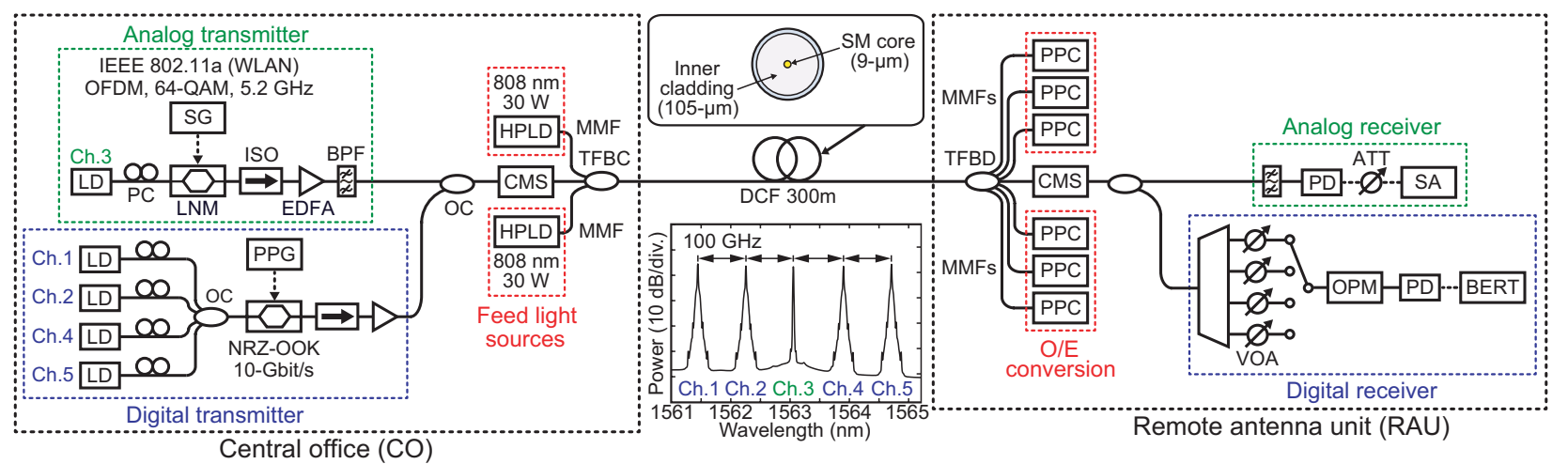

Fig. 2 Experimental setup for multichannel data transmission with $60-\mathrm{W}$ power-over-fiber feed using a DCF. 
が伝送されていることになる。そのうち，およそ半分 が300 m DCFでの伝送損失で, 残りの半分がTFBDでの 分岐損失になる。電気電力の伝送効率については, 実験 に使用したPPCの光電変換効率がおよそ25\%だったた め，平均でおよそ $11.7 \%$ となった。 これにより，60 Wの 給電光入力下で, $7 \mathrm{~W}$ を超える電気電力を光ファイバ給 電で送電することが可能であることがわかった。この值 は従来技術の 100 倍に匹敵する給電能力を有しており, 小型の無線基地局であれば, 単独駆動も可能な電気電力 を供給可能であることを示している.

併せて, 給電下における信号光の伝送品質の評価も 行った. 光アナログ信号においては, 元信号 (Back-toback)に対するEVMペナルティ評価で, 給電光パワーに よらず，ペナルティが $0.04 \%$ 以下となった，光デジタル 信号に抽は，元信号に対するパワーペナルティ評価 で, 全ての伝送信号でペナルティが $0.17 \mathrm{~dB}$ 以下を達成 した。 これらのペナルティの值は誤差レベルに相当する ほどに小さいものであることから，全てのチャネルにお いて, 給電光の有無に影響されない高い伝送品質を得ら れることを示しており，DCFによる光ファイバ給電技術 の有効性を明らかにしていると言える.

\section{MMFを用いた光ファイバ給電技術}

DCFを用いることで, 従来技術と比較して, 高パワー な電力伝送を実現したものの, 汎用性の高い光ファイバ による給電技術の検討も重要である。そこで, 著者ら は, MMFを用いた光ファイバ給電技術の研究開発も 行っている。先述したように, MMFで問題となるのが, 信号光の帯域制限の要因となるモード分散と, 同コア内 を伝搬する給電光の強度摇らぎや雑音等によって発生す る信号光へのクロストークの影響である。実際に先述の MMFを用いた光ファイバ給電技術では, 信号光と給電 光を異なる光ファイバを用いて伝送している ${ }^{6,7)}$. この 問題を同時に克服するため, 著者らは, MMFへの光 ビーム入射法を利用した抑制法 ${ }^{14,15)}$ に着目をした。信号 光や給電光がSMFで生成・伝搬された際，伝送路になる MMFに信号光が入射されることになるが，ここで信号 光のビーム入射位置を調整することで伝送する伝搬モー ドの大まかな制御を行うことが可能である。1つがMMF のコア中心軸からおよそ10 $\mu \mathrm{m}$ ほど離れた位置でSMFか らの光ビーム入射を行うことで，信号光を高次モードで
伝搬可能なオフセットラウンチ (Offset Launching: OL) で ある ${ }^{14)}$ 。また，ビーム入射位置を中心軸に合わせ， SMF とMMFの間に中間コア径のファイバを挿入するか, 融 着接続の際の融着条件を調整することで, SMFとMMF 間のコア径差に段階を付けてビーム入射し，低次モード での伝搬を可能にするセンターラウンチ (Center Launching: CL) がある ${ }^{15)}$ 、いずれの場合も伝搬モードに制約を 与えることになるため, モード分散の抑制が可能であ る。そこで，著者らは，信号光に対してOLによる高次 モード伝搬, 給電光に対してCLによる低次モード伝搬 を行うことで，MMF内で発生する信号光のモード分散 を抑制しつつ，両者の伝搬モードの違いを活用した融合 技術によって, 給電光によるクロストークも抑制すると いう手法を新たに提案した ${ }^{16)}$.

Fig. 4 に実験構成を示す，信号光には，波長 $1310 \mathrm{~nm}$ のLD出力をLNMで変調することで生成した光アナログ 信号を利用した。信号光は半導体光増幅器 (Semiconductor Optical Amplifier: SOA) で増幅後, モードコンディ ショニングパッドコード (Mode Conditioning Patch-code: $\mathrm{MCP})$ に入射した，MCPは挿入図にあるように， SMFと MMF間をおよそ10 $1 \mathrm{~m}$ の軸ズレで接続された受動素子 で，市販品の光ファイバコードとして容易に入手可能な ものである。これにより，信号光をOLの状態でMMF内 に入射させている。一方，給電光には波長 $1550 \mathrm{~nm}$ ，最 大出力 $10 \mathrm{~W}$ の高出力光ファイバレーザー (High-Power Fiber Laser: HPFL) を使用した。本研究では長距離伝送の 際にも給電光の高いパワー伝送効率を得るため, 最も伝 送損失の低い $1550 \mathrm{~nm}$ 帯の光源を使用した。CLについて は, HPFLのSMF出力とMMF伝送路間の融着接続の際 に，融着回数を調整し，CLの条件に合うように設定し た。マルチモード波長多重カプラ (Wavelength Division Multiplexing Coupler: WDMC) で信号光と給電光を合波 後, コア直径62.5 $\mu \mathrm{m}$ のMMFを $2 \mathrm{~km}$ しくは4 km伝送 し, 再度WDMCで分波を行った. 給電光は光パワー メータ (Optical Power Meter: OPM) に入射され，伝送さ れた給電光パワーを測定し，パワー伝送効率を評価し た。信号光はPDで電気信号に変換された後，SAでEVM による信号品質評価を行った。

給電光のパワー伝送効率の評価においては, $2 \mathrm{~km}$ 伝 送では73\%，4 km伝送では60\%となり，DCFと比較して 高い伝送効率を得た。その要因としては, 給電光波長 が1550 nmで，WDMCの挿入損失がTFBDよりも小さい

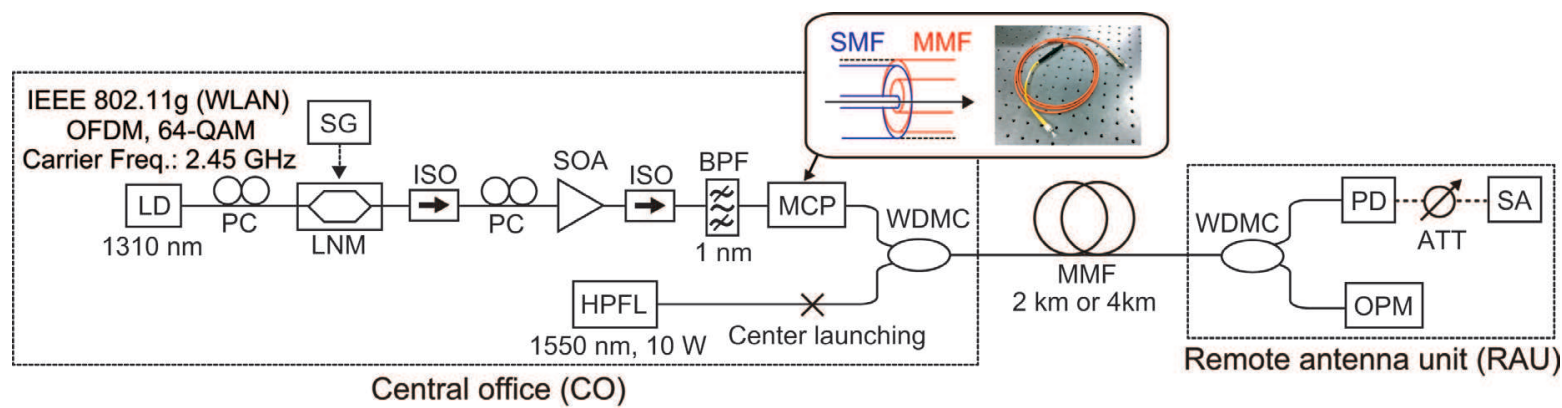

Fig. 4 Experimental setup for RoF transmission with 10-W power-over-fiber feed using an MMF. 


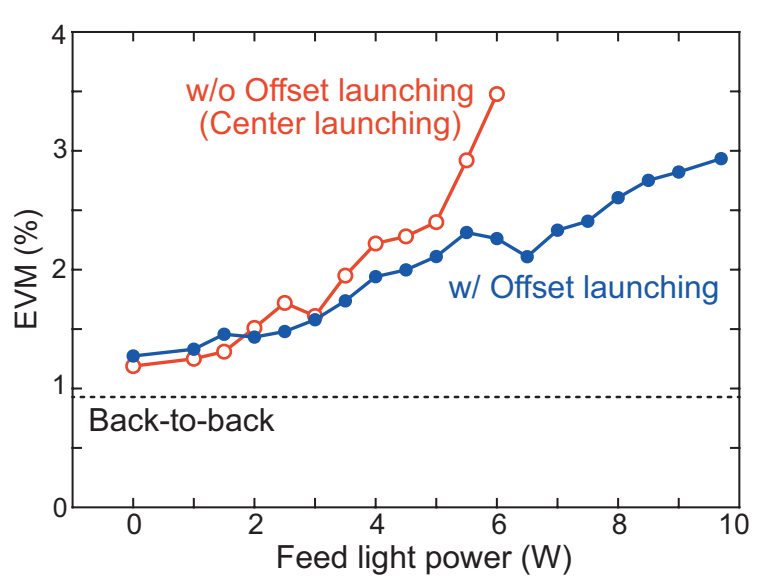

Fig. 5 EVM value as a function of feed light power in $4 \mathrm{~km}$ downlink transmission.

ためである。このため, 給電光の波長も含め, $\mathrm{km}$ オー ダーのパワー伝送においては, MMFによる光ファイバ 給電の方が有利と言える.

Fig. 5 に $4 \mathrm{~km}$ 下り伝送でのEVM特性を示す. 図中の点 線は光ファイバを伝送する前の元信号 (Back-to-back)の 信号品質であるEVMを示しており，伝送後の信号はこ れを基準にどのくらい信号品質が変化しているかを評価 している，給電光パワーが小さいときにはほとんど差異 はないが, 給電光のパワーが増大するとOLのない(代わ りにCLを用いた) 信号光の場合は, EVMの值が急激に劣 化し, 給電光パワー6 W以上ではEVMの測定も不可能と なった。 これに対し, 給電光パワーの影響があるもの の，OLを用いた場合は，10 W給電下で4 km伝送するこ とが達成された。これにより，OLを用いることで給電 光によるクロストークが抑制されているのが確認され た. 尚, 上り伝送については, 給電光と信号光が逆方向 に伝送するため, 給電光の強度ゆらぎや雑音の影響は対 向して伝送するうちに平均化され信号品質にほとんど影 響を与えない。このため, OLの有無によらず, クロス トークは確認されなかった。
5. まとめ

無線基地局の駆動を目的とした光ファイバ給電技術に ついて，著者らの研究成果を中心に解説した，光ファイ バの特徴を活かした伝送技術を活用することで，従来技 術を大きく凌駕する給電能力が得られることを示した. ここ最近, 高出力レーザーや光電変換素子の高性能化が 急速に進んでいる状況になってきている。これらの進歩 も後押しとなり，光エネルギーを用いた給電技術全般が 大きく発展していくことを期待したい.

\section{参考文献}

1) Cisco System Inc.: Cisco Visual Networking Index, White Paper (2017).

2) NTTドコモ：ドコモ5Gホワイトペーパー(2014).

3）陰井敬義：東海防災情報セミナー資料(2015).

4) K. Sone, I. Lim, X. Wang, Y. Aoki, H. Seki, and J. C. Rasmussen: Proc. 21st Opto-Electronics Commun. Conf., 2016 (IEICE, Niigata, 2016) TuA4-2.

5) T. Miki, K. Kawano, N. Nakajima, N. Kishi, M. Miyamoto, and T. Aoki: Proc. 8th Opto-Electronics Commun. Conf., 2016 (Shanghai, China, 2003) 16D3-4.

6) D. Wake, A. Nkansah, N. J. Gomes, C. Lethien, C. Sion, and J.-P. Vilcot: J. Lightwave Technol. 26 (2008) 2484.

7) C. Lethien, D. Wake, B. Verbeke, J.-P. Vilcot, C. Loyez, M. Zegaoui, N. Gomes, N. Rolland, and P.-A. Rolland: IEEE Photon. Technol. Lett. 24 (2012) 649.

8) T. Umezawa, K. Kashima, A. Kanno, A. Matsumoto, K. Akahane, N. Yamamoto, and T. Kawanishi: J. Quantum Electron. 23 (2017) 3800508.

9) J. Sato and M. Matsuura: Proc. 18th Opto-Electronics Commun Conf., 2013 (IEICE, Kyoto, 2013) TuPO-8.

10) M. Matsuura and J. Sato: IEEE Photon. J. 7 (2015) 7900609.

11) M. Matsuura, H. Furugori, and J. Sato: Opt. Lett. 40 (2015) 5598.

12) M. Matsuura and Y. Minamoto: J. Lightwave Technol. 35 (2017) 979.

13) D. Kamiyama, A. Yoneyama, and M. Matsuura: IEEE Photon. Technol. Lett. 30 (2018) 646.

14) L. Raddatz, I. H. White, D. G. Cunningham, and M. C. Nowell: J Lightwave Technol. 16 (1998) 324.

15) D. Sim, Y. Takushima, and Y. C. Chung: J. Lightwave Technol. 27 (2009) 1018.

16) H. Kuboki and M. Matsuura: Opt. Lett. 43 (2018) 1057. 